\title{
On the inflammatory response in metal-on-metal implants
}

\author{
Ulrike Dapunt ${ }^{1 *}$, Thomas Giese ${ }^{2}$, Felix Lasitschka ${ }^{3}$, Jörn Reinders ${ }^{1}$, Burkhard Lehner ${ }^{1}$, Jan Philippe Kretzer ${ }^{1}$, \\ Volker Ewerbeck ${ }^{1}$ and Gertrud Maria Hänsch ${ }^{2}$
}

\begin{abstract}
Background: Metal-on-metal implants are a special form of hip endoprostheses that despite many advantages can entail serious complications due to release of wear particles from the implanted material. Metal wear particles presumably activate local host defence mechanisms, which causes a persistent inflammatory response with destruction of bone followed by a loosening of the implant. To better characterize this inflammatory response and to link inflammation to bone degradation, the local generation of proinflammatory and osteoclast-inducing cytokines was analysed, as was systemic T cell activation.
\end{abstract}

Methods: By quantitative RT-PCR, gene expression of cytokines and markers for T lymphocytes, monocytes/macrophages and osteoclasts, respectively, was analysed in tissue samples obtained intraoperatively during exchange surgery of the loosened implant. Peripheral T cells were characterized by cytofluorometry before surgery and 7 to 10 days thereafter.

Results: At sites of osteolysis, gene expression of cathepsin K, CD14 and CD3 was seen, indicating the generation of osteoclasts, and the presence of monocytes and of T cells, respectively. Also cytokines were highly expressed, including CXCL8, IL-1ß, CXCL2, MRP-14 and CXCL-10. The latter suggest T cell activation, a notion that could be confirmed by detecting a small, though conspicuous population of activated CD4+ cells in the peripheral blood T cells prior to surgery.

Conclusion: Our data support the concept that metallosis is the result of a local inflammatory response, which according to histomorphology and the composition of the cellular infiltrate classifies as an acute phase of a chronic inflammatory disease. The proinflammatory environment, particularly the generation of the osteoclast-inducing cytokines CXCL8 and IL $1-\beta$, promotes bone resorption. Loss of bone results in implant loosening, which then causes the major symptoms of metallosis, pain and reduced range of motion.

Keywords: Metal-on-metal implants, Metal wear particles, Innate immune response, T-cell response, Cytokines, Osteolysis

\section{Background}

In patients with osteoarthritis, replacement of dysfunctional joints by endoprostheses is the therapy of choice. Particularly total hip replacement is rated as the most successful surgical intervention in the field of orthopaedics (reviewed in [1]). An abundance of implants are available at the surgeons demand. Because of direct contact of the implanted devices with tissues and serum mediator systems, materials are designed to be biologically inert, and to allow the ingrowth of tissue cells, such as osteoblasts and fibroblasts without eliciting adverse reactions from the patients.

\footnotetext{
* Correspondence: Ulrike.Dapunt@med.uni-heidelberg.de

${ }^{1}$ Department of Orthopaedics and Trauma Surgery, University Hospital Heidelberg, Schlierbacher Landstrasse 200a, 69118 Heidelberg, Germany Full list of author information is available at the end of the article
}

Unfortunately, implanted materials can release wear particles which may elicit adverse reactions in patients, apparent as localized inflammation with tissue damage and bone degradation which finally results in loosening of the implant (reviewed in [2]).

A special situation arises when so-called metal-on-metal hip resurfacing implants are used. They have been introduced especially for younger, active patients because healthy bone is spared by this device (reviewed in $[3,4]$ ) (see also Figure 1). Unfortunately, some metal-on-metal implants release large amounts of wear particles, which are deposited in the tissue and elicit adverse tissue reactions [5-12] (see also Figure 1). This condition has been described many years ago [13-15] and when patients experience severe pain at the site of the implant and reduced range of motion, 
A


$\mathrm{B}$

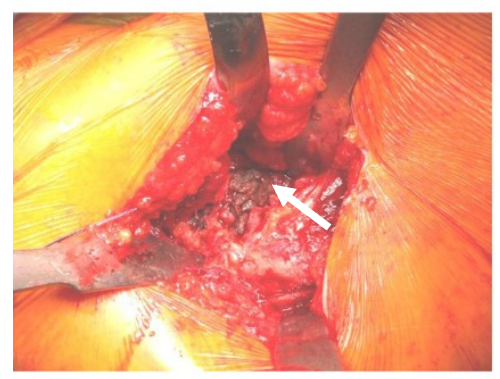

C
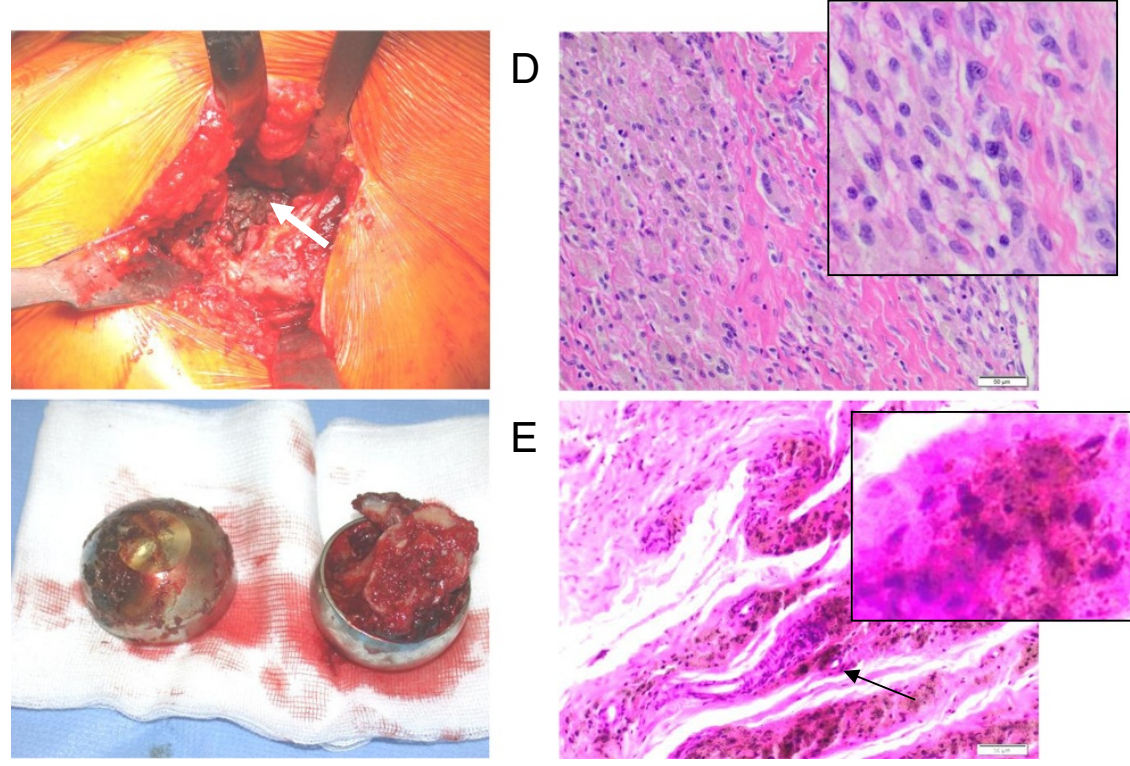

E



Figure $\mathbf{1}$ Clinical and histological images. A Shown are x-rays of a patient with a metal-on-metal hip resurfacing implant (left) and on the right of a patient with a total hip joint replacement. B After the removal of the implant, deposition of metal particles is seen as is the formation of a pseudotumour (arrow). C The removed implants are shown; they are "empty" due to bone loss. D, E Biopsies from an osteolytic site show infiltration of leukocytes, particularly of mononuclear cells, and deposits of metal wear particles.

the implant has to be replaced. So far, specific diagnostic tools are not available, though elevated concentrations of metal ions in the blood point towards an increased wear [16]. Radiologic examination might reveal a deterioration of bone around the implant, which could be responsible for a loosening of the implant. A greyish coloring of the tissue might be seen macroscopically when the implant is removed.

Histology of tissue derived from patients with metallosis shows a wide spectrum of changes. Areas of metal deposits present with granulomatous inflammation, infiltrates of monocytes and $\mathrm{T}$ cells, and occasionally giant cells. In some patients tumour-like tissue formations, so-called "pseudotumours", are found in close proximity of the implant, in others a perivascular accumulation of lymphocytes. [17-20]. The difference in morphology could reflect different underlying pathomechanisms, for example distinct responses to a higher versus a lower load of metal particles, or alternatively, different stages of the disease $[21,12]$.
Basically, metallosis is thought to be the result of an immune reaction to the metal wear particles. A participation of phagocytic cells is presumed, because they readily take up particulate materials, and because they are activated during that process to produce pro-inflammatory cytokines (reviewed in [22]). A hypersensitivity towards metals in form of a specific $\mathrm{T}$ cell mediated immune response has also been suggested; a classical "type IV immune responses" towards metal/metal ions, however, occurs only in a few patients $[23,24]$, leading to the notion that an allergic reaction to metal ions is not a common denominator of metallosis. Moreover, some studies failed to show typical $\mathrm{T}$ cell activation markers or characteristic $\mathrm{T}$ cell-derived cytokines [25]. However, due to their short half-life some cytokines might escape detection by conventional methods, and therefore a participation of $\mathrm{T}$ cells in the progression of metal-induced tissue damage cannot be excluded. In the present study we examined the local generation of cytokines by gene expression analysis, particularly with regard 
to $\mathrm{T}$ cell-derived cytokines, and the possible link to bone degradation. Moreover, systemic $\mathrm{T}$ cell activation in patients was assessed.

\section{Patients, materials and methods Patients}

Five patients undergoing revision surgery due to a hip resurfacing implant (metal-on-metal, ASR Hip System, DePuy) and six patients suffering from aseptic loosening of a total hip replacement (metal-on-polyethylene or ceramic-on-polyethylene) were included in the study. Diagnosis of loosening was based on patient's complaints, clinical examination and by conventional $\mathrm{x}$-ray and/or CT-scan (patients' clinical data are summarised in Table 1). The study was approved by the local ethic committee, and informed consent was obtained from the patients.

\section{Collection of tissue and blood samples}

During surgery, soft tissue samples were taken from the cup, the capsule, the femur and for comparison from muscle in a standardized fashion. The tissue samples were divided, a part was fixed in formalin and conserved for histological analysis, and another was placed into
RNAlater (Ambion, Lifetechnologies, Heidelberg, Germany) for quantitative PCR analysis. Immediately before surgery, and 7 to 10 days thereafter, peripheral blood was collected into heparinized tubes and cells were subjected to cytofluorometry (see below).

\section{Histology}

For routine histological evaluation, the samples were embedded in paraffin, decalcified, and sections of 3 to $4 \mu \mathrm{M}$ were prepared for eosin-haematoxylin staining.

\section{Gene expression analysis}

The tissue samples were disrupted with RiboLyser devices (ThermoHYBAID, Heidelberg, Germany) containing $400 \mu \mathrm{l}$ lysis buffer from the MagnaPure mRNA Isolation Kit containing 1\%DTT (v/w) (ROCHE Diagnostics, Mannheim, Germany). mRNA was isolated with the MagnaPure-LC device using the mRNA- standard protocol for cells. An aliquot of mRNA was reversely transcribed using AMV-RT and oligo- (dT) as primer (First Strand cDNA synthesis kit, ROCHE Diagnostics, Mannheim, Germany) according to the manufactures protocol in a thermocycler. Primer sets optimized for the LightCycler (RAS, Mannheim Germany)

Table 1 Patients' clinical and laboratory findings ( metallosis and aseptic loosening)




were purchased from SEARCH-LC GmbH (www.SearchLC.com). The PCR was performed with the LightCycler ${ }^{\circ}$ FastStart DNA Sybr GreenI kit (RAS) according to the protocol provided. To control for specificity, a melting curve analysis was performed. The copy number was calculated from a standard curve, obtained by plotting known input concentrations of four different plasmids at log dilutions to the PCR-cycle number (CP) at which the detected fluorescence intensity reaches a fixed value. To correct for differences in the content of mRNA, the calculated transcript numbers were normalized according to the expression of the housekeeping gene peptidylprolyl isomerase B (PPIB). Values were thus given as transcripts per 1000 transcripts of PPIB.

\section{Cytofluorometry}

The following antibodies were used: CD4 PerCP, CD8 PerCP, CD11b PE, CD28 FITC (all Becton Dickinson, Heidelberg, Germany), and the respective isotype: mouse IgG1-PerCP, mouse IgG1-PE (all Becton Dickinson, Heidelberg, Germany) and IgG1-FITC (Beckman Coulter, Marseille, France). Whole heparinized blood (100 $\mu$ l) was incubated with the respective antibodies $(20 \mathrm{~min}$, room temperature), erythrocytes were then lysed by Facs Lysing solution and cells were washed and fixed with $1 \%$ paraformaldehyde. Cells were analysed by FacsCalibur using CellquestPro 3.0 as software (Becton and Dickinson, Heidelberg, Germany).

\section{Statistical analysis}

Differences between groups were calculated using Friedman test and Mann-Whitney test, respectively (as indicated in the figure legends or tables).

\section{Results}

\section{Macroscopic and histological aspects of metallosis}

Five patients with metallosis and six patients with aseptic loosening were included in the study (patients' data are summarised in Table 1). The implant used in patients developing metallosis is shown in Figure 1A. In comparison to other forms of endoprostheses, the femur is better preserved, but because of the metal-on-metal contact, metal wear particles accumulate at the site, macroscopically seen as greyish colouring (Figure 1B). In this example, also pseudotumour formation occurred (Figure 1B), as did osteolysis (Figure 1C). Biopsies taken from the site showed metal wear particles, and also a cellular infiltrate, consisting mainly of mononuclear cells (Figure 1D,E).

\section{Gene expression of cathepsin K, CD3, CD14 and of cytokines in tissue}

Tissue samples from the cup and from the femoral bone were taken from areas that were exposed after removal of the implant. Moreover, samples from the capsule and when present from the pseudotumour, were gathered and for comparison, from distant muscle as an unaffected site. Gene expression of CD14 as marker for monocytes/macrophages, of CD3 as marker for T cells and of cathepsin K, characteristic for osteoclasts, was determined by quantitative PCR. At the primary osteolytic site, the cup, expression of cathepsin K, CD14 or CD3 was considerably higher compared to expression in muscle (Figure 2). The absolute numbers varied widely among the patients, but the expression pattern was similar.

In the same tissues, gene expression of proinflammatory cytokines was analysed. CXCL8 (interleukin (IL)-8), IL-1ß, CXCL2 (macrophage inflammatory protein, MIP2 $\alpha$ ) and MRP14 (S100A9) were highly expressed in tissue of the cup, again with a wide variation among the patients (Table 2). Gene expression of TNF $\alpha$ (tumour necrosis factor alpha), RANK (receptor activator of NfkB) or RANK ligand (RANKL) was rather low in all tissues. The monocyte chemotactic protein, MCP-1 (CCL2) was found in all tissues with no apparent preference, as was CXCL10 (IP-10).

To address the question whether aspects of the cytokine expression pattern were typical for metallosis, we




Table 2 Gene expression of cathepsin K, CD3, CD14 and of cytokines in tissue of patients with metallosis

\begin{tabular}{llll}
\hline Parameter & Cup & Muscle & $\begin{array}{l}\text { Difference between } \\
\text { groups calculated by } \\
\text { Mann-Whitney test }\end{array}$ \\
\hline Cathepsin K & $2603.0 \pm 1220.8^{*}$ & $968.4 \pm 392.4$ & n.d. \\
CD3 & $288.6 \pm 262.2$ & $42.2 \pm 26.4$ & $p=0.036$ \\
CD14 & $1806.2 \pm 1211.9$ & $334.2 \pm 247.7$ & $p=0.012$ \\
CXCL8 & $677.0 \pm 355.5$ & $27.0 \pm 20.8$ & $p=0.043$ \\
IL1ß & $101.4 \pm 90.7$ & $9.0 \pm 3.5$ & $p=0.043$ \\
CXCL2 & $276.5 \pm 125.0$ & $92.8 \pm 51.5$ & $p=0.040$ \\
MRP14 & $82376.8 \pm 78340.0$ & $377.4 \pm 396.0$ & $p=0.040$ \\
RANK & $10.9 \pm 9.8$ & $8.2 \pm 5.7$ & n.d. \\
RANKL & $4.1 \pm 4.0$ & $0.2 \pm 0.2$ & n.d. \\
TNFa & $11.5 \pm 4.0$ & $7.3 \pm 1.0$ & n.d. \\
CXCL10 & $184.7 \pm 239.5$ & $131.6 \pm 147.8$ & n.d. \\
CCL2 & $1612.1 \pm 1958.9$ & $652.0 \pm 144.8$ & n.d. \\
\hline
\end{tabular}

*copy number; n.d. = not different.

compared the data with those obtained from patients requiring replacement of a hip implant because of aseptic loosening.

Because for both patient groups tissue from the capsule and from the femoral bone was available, gene expression in these tissue were used, although these were not the primary osteolytic sites, particularly not in patients with metallosis. As summarised in Table 3, for metallosis patients essentially the same expression pattern was seen: in tissue from either capsule or femoral bone, expression of CXCL8, IL-1ß, CXCL2 and MRP14 was higher compared to muscle tissue, as was expression of CD14. In patients with aseptic loosening, in contrast, no major differences in cytokine expression were observed between muscle and the other tissues; only CD14 was expressed to a higher extent in femoral bone. In patients with metallosis, CXCL8 and IL-1ß expression was higher by trend than in patients with aseptic loosening; CXCL2 and CXCL10 were significantly higher expressed in patients with metallosis (Table 3).

Gene expression of CD3, CD14 and of the cytokines was also determined in peripheral blood cells of the patients. No major differences were observed between blood cells from patients with metallosis or with aseptic loosening (data not shown). Only expression of CXCL10 was higher in blood cells of metallosis patient compared to patients with aseptic loosening $(9.4 \pm 4.1$ copies versus $1.7 \pm 1.75)$.

\section{Analysis of $\mathrm{T}$ cell response}

Peripheral blood $\mathrm{T}$ cells were analysed for expression of activation-associated receptors. As sensitive markers, down-modulation of CD28 and up-regulation of CD11b on CD4+ and CD8+ T cells was measured (example in Figure 3A). Because the percentage of CD4 + CD28- and CD8 + CD28- cells varies greatly among donors (mean \pm $\mathrm{SD}$ of $\mathrm{n}=18: 6.51 \pm 5.59 \% \mathrm{CD} 4+\mathrm{CD} 28-$ and $37.4 \pm 20.3 \%$ $\mathrm{CD} 8+\mathrm{CD} 28-$ ) [26], and because the activation of $\mathrm{T}$ cells is transient, we determined the $\mathrm{T}$ cell population in the patients immediately before surgery and 7 to 10 days thereafter. There were no major differences regarding CD8 + CD28- cells, whereas CD4 + CD28- cells were seen in patients with metallosis (and not in patients with aseptic loosening) (Figure 3B). CD11b upregulation occurred in both, CD4+ and CD8+, and the percentage declined after surgery, as did the mean values of $\mathrm{CD} 11 \mathrm{~b}$ (Figure 3C).

Table 3 Cytokine expression in tissue of patients with metallosis versus aseptic loosening

\begin{tabular}{|c|c|c|c|c|c|c|}
\hline & & sule & Fen & & & scle \\
\hline & Metallosis & Aseptic loosening & Metallosis & Aseptic loosening & Metallosis & Aseptic loosening \\
\hline CXCL8 & $1927.3 \pm 328.4+$ & $106.2 \pm 106.6$ & $580 \pm 316.2$ & $379.2 \pm 494.1$ & $27 \pm 20.8+$ & $181.3 \pm 305.4$ \\
\hline$\| \mathrm{L}-1$ & $179.5 \pm 293.5+$ & $11.2 \pm 12.1$ & $65 \pm 44.7$ & $47.9 \pm 48.4$ & $9 \pm 3.5+$ & $12.2 \pm 18.8$ \\
\hline RANK & $5.6 \pm 5.9$ & $9.5 \pm 8.8$ & $11 \pm 4.5$ & $26.3 \pm 32.7$ & $8.2 \pm 5.7$ & $19.3 \pm 22.9$ \\
\hline RANKL & $4.4 \pm 7$ & $17.3 \pm 18.7$ & $11 \pm 8.2$ & $44.7 \pm 50.2$ & $0.2 \pm 0.4$ & $2 \pm 4.9$ \\
\hline Cathepsin K & $2708.8 \pm 2139.7$ & $4794.9 \pm 2817.2$ & $3313.3 \pm 1646.1$ & $6871.6 \pm 4937.7$ & $968.4 \pm 392.4$ & $2958.5 \pm 3390.7$ \\
\hline CCL2 & $2005.7 \pm 1321.5$ & $990.7 \pm 512.6$ & $3439.8 \pm 2892.6$ & $1196.3 \pm 575.3$ & $652 \pm 144.8$ & $1065.8 \pm 1030.5$ \\
\hline CD14 & $1075.5 \pm 659.1+$ & $563.2 \pm 321+$ & $823.8 \pm 488.9$ & $687.8 \pm 417.2$ & $288.8 \pm 151.3+$ & $305.2 \pm 175+$ \\
\hline CD3 & $64.1 \pm 59.8$ & $29.5 \pm 15.7$ & $111.5 \pm 77.1$ & $62.2 \pm 69.9$ & $42.2 \pm 26.5$ & $45.7 \pm 19.3$ \\
\hline TNFa & $10.6 \pm 10$ & $3.7 \pm 2.2$ & $12.8 \pm 7$ & $5.7 \pm 3.7$ & $5.8 \pm 3.3$ & $4.2 \pm 6.2$ \\
\hline CXCL10 & $241.4 \pm 246.2^{*}$ & $25.9 \pm 17.6$ & $183.8 \pm 130^{*}$ & $41.7 \pm 26.9 *$ & $131.6 \pm 147.8$ & $607.2 \pm 1167.8$ \\
\hline MRP14 & $4899 \pm 2656.3 *$ & $806 \pm 65$ & $48214.3 \pm 91617.3^{*}$ & $2461.3 \pm 2529.1$ & $377.4 \pm 396$ & $2186.7 \pm 2080.3$ \\
\hline CXCL2 & $241.2 \pm 126.5 *$ & $73.2 \pm 59.2$ & $670 \pm 635.2$ & $133.8 \pm 100.2$ & $92.8 \pm 51.6$ & $262.3 \pm 467.9$ \\
\hline
\end{tabular}

The bold print indicates that the groups differ significantly as tested by Mann-Whitney test; ${ }^{*}$ indicates differences between metallosis and aseptic loosening; the + differences between capsule/femoral bone tissue and muscle. 

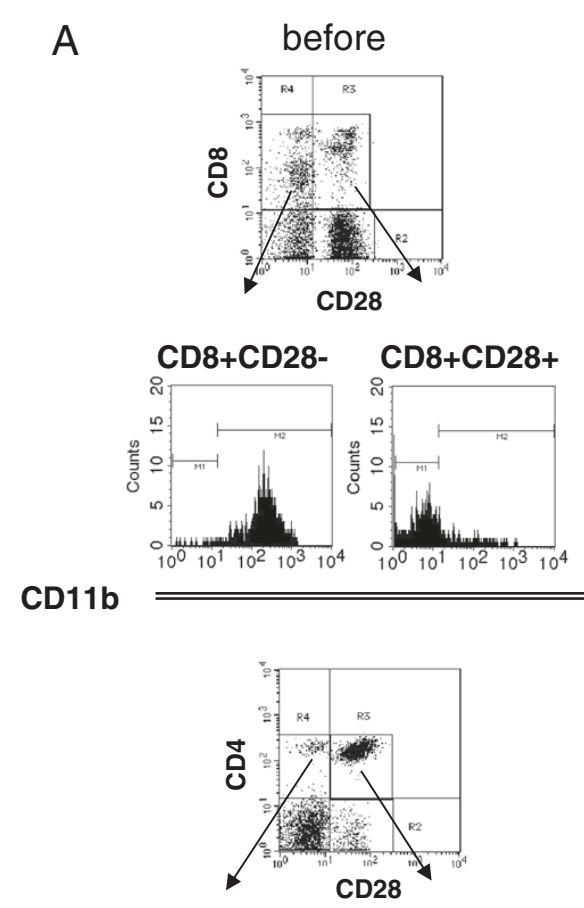

CD4+CD28- CD4+CD28+



B

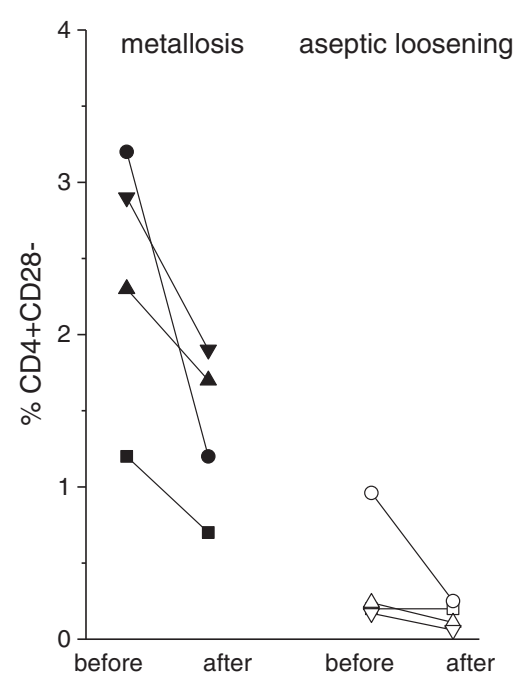

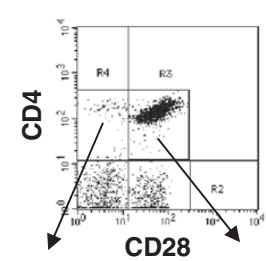



CD8+CD28- CD8+CD28+

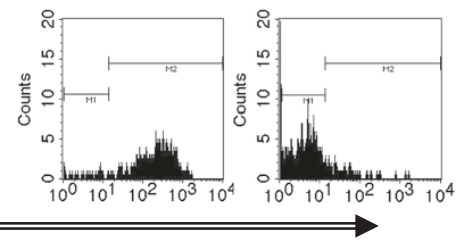

CD4+CD28- CD4+CD28+


C

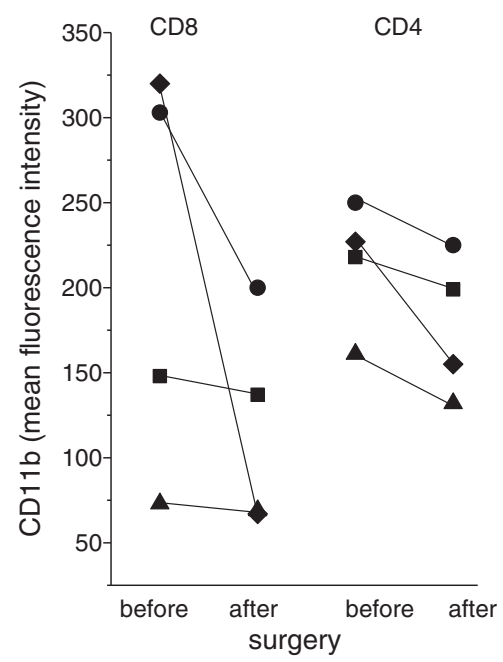

Figure $\mathbf{3}$ (See legend on next page.) 
(See figure on previous page.)

Figure 3 Cytofluorometry of peripheral T cells. A By cytofluorometry the peripheral T cells of a patient before and 9 days after surgery were analysed. Before surgery, $57.0 \%$ of CD8+ cells were negative for CD28, but only $45.6 \%$ after surgery; and $7.4 \%$ of CD4 versus $4.6 \%$ after surgery. The CD8 + CD28- and CD4 + CD28- cells expressed CD1 1b, indicative of an activated T effector cell. B Shown is the percentage of CD4 + CD28- cells in patients with metallosis (left) or patients with aseptic loosening (right) before and after surgery. C The mean fluorescence intensity of CD1 1 b on T cells declined after surgery (shown are data of four patients; each symbol refers to one patient and data obtained before and after surgery are connected by a line).

\section{Discussion}

To get insights into the local immune response in patients with metal-on-metal implants, tissue derived from osteolytic sites was explored with regard to infiltrating leukocytes, generation of osteoclasts and production of pro-inflammatory cytokines by gene expression analysis. High expression of CD14 and of CD3 indicative of monocyte and T cell infiltration was seen, as was expression of cathepsin $\mathrm{K}$, an enzyme typically expressed by osteoclasts. In osteolytic tissue also genes encoding for pro-inflammatory cytokines, including CXCL8, IL-1ß, CXCL2 and MRP14 were highly expressed, reflecting a localized inflammatory response. Expectedly, the number of gene transcripts varied widely among the patients, reflecting the fact that most likely multiple factors contribute to metallosis, such as the abundance and size of the wear particles; the exposure time of the local cells to wear particles; and also hostinherent factors, particularly the responsiveness of leukocytes to irritants, and their capacity to synthesize and release cytokines.

With regard to osteolysis, gene expression of CXCL8, IL- $1 ß$ and CXCL2 are of special interest. These are all multifunctional cytokines that can promote the inflammatory response, for example by attracting and activating more leukocytes. Moreover, CXCL8, IL-1ß and CXCL2 can induce the generation of osteoclasts from precursor cells, either directly or in combination with other cytokines [27-29]. The high expression of these cytokines could explain that osteolysis occurs despite our finding that RANK and RANKL, which are described as crucial in induction of osteoclastogenesis in other conditions, are only marginally expressed [30-32].

In patients with metallosis gene expression of cytokines, particularly of CXCL2 and CXCL10, was higher compared to patients with aseptic loosening of a total joint replacement. Due to the small number of patients and the wide variation among the patients the data have to be interpreted with caution. Possibly, metal wear particles elicit a more prominent inflammation than wear particles derived from metal-on-polyethylene or ceramic-on-polyethylene implants. This explanation is supported by the fact that in the latter implants, expression of most cytokines at osteolytic sites did not exceed that in muscle. A qualitative different inflammatory response, however, cannot be ruled out.
The most likely source for CXCL8, CXCL2, IL-1ß and MRP-14 are phagocytic cells, particularly infiltrated monocytes, which - according to the literature - are activated by wear particles. Monocyte infiltration as determined by CD14 gene expression was higher in patients with metallosis, and to some extent reflects an activation on monocytes, because it is known to be associated with enhanced CD14 synthesis [33]. Whether monocyte activation by metal-on-metal implants differs in principle from metal-on-polyethylene or ceramic-on-polyethylene implants or whether it is only a quantitative difference cannot be decided as yet, nor can we deduce from our data whether this contributes to the lower cytokine expression in patients with aseptic loosening.

CXCL8 and CXCL2 are also chemotactic for T cell subpopulations [34-36] and T cell infiltrates were also seen in patients with metallosis. Infiltration indicates an activation of $\mathrm{T}$ cells; as typical $\mathrm{T}$ cell-derived cytokine interferon gamma was indirectly assessed by determining CXCL10. In the tissue, expression varied widely among the patients with a trend towards higher expression in patients with metallosis compared to patients with aseptic loosening. CXCL10 was also found in peripheral blood T cells of patients with metallosis, but not in the blood of patients with aseptic loosening. Although the number of transcripts was rather low, the data point to an activation of $\mathrm{T}$ cells in metallosis. The interpretation is supported by the presence of CD4+ and CD8+ cells which were CD28 negative and expressed CD11b, a phenotype corresponding to an activated effector cell [26,37]. The percentage of CD4 + CD28- cells declined within days after removal of the implant, as did the percentage of CD4+ or CD8+ cells expressing CD11b. Because CD $8+$ CD28- are longlived and remain longer in the circulation, the population of CD8 + CD28- did not change as convincingly as CD4 + CD28-.

The presence of activated effectors in the peripheral blood and the decline following removal of the implant is compatible with the presumption that the $T$ cells are activated in metallosis patients, but not in patients with aseptic loosening. Systemic activation of $\mathrm{T}$ cells could be a prerequisite for their emigration from the blood vessel into an inflammatory site. The perivascular accumulation of lymphocytes [20,21] as it is described in patients with metallosis as "ALVAL" (aseptic lymphocytic 
vasculitis associated lesion) could reflect this $\mathrm{T}$ cell trafficking.

How a systemic $\mathrm{T}$ cell activation occurs is still under investigation. A specific immune response to metal ions in terms of a type IV hypersensitivity is not regularly seen in metallosis patients [23,24,38]. Possibly, metal-loaded monocytes or macrophages emigrate to the lymph nodes encountering $\mathrm{T}$ cells there, and activate the cells by a not yet defined mechanism. Alternatively, metal ions in the blood could affect $\mathrm{T}$ cells and $\mathrm{T}$ cell function, as it has already been reported for tissue cells $[39,40]$.

\section{Conclusion}

In conclusion, we consider metallosis as a clinical entity, caused by a local inflammatory response, which according to histomorphology and the composition of the cellular infiltrate classifies as an acute phase of chronic inflammatory disease. The inflammation persists because of the constant triggering wear particles, which are released from the implant over time, and possibly also by self-perpetuating cytokine-driven processes. The proinflammatory environment favors the generation of bone resorbing cells; loss of bone ensues in implant loosening, which then causes the major symptoms of metallosis: pain and a reduced range of motion.

\section{Competing interests}

The authors declare that they have no competing interests.

\section{Authors' contributions}

The following authors have made substantial contributions to conception and design of the study: UD, TG, GMH. -The following authors have made substantial contributions to acquisition of data or analysis and interpretation of data: UD, TG, GMH, FL, JR. -The following authors have been involved in drafting the manuscript or revising it critically for important intellectual content: UD, TG, GMH, FL, JR, JPK, BL, VE. -The following authors have given final approval of the version to be published and agree to be accountable for all aspects of the work in ensuring that questions related to the accuracy or integrity of any part of the work are appropriately investigated and resolved: UD, TG, GMH, FL, JR, JPK, $B L, V E$. All authors read and approved the final manuscript.

\section{Acknowledgment}

The skillful technical assistance of Birgit Prior and Sabine Stegmaier is gratefully acknowledged; we also thank the colleagues from the Department of Orthopedics and Trauma Surgery for collecting the tissue samples and Simone Gantz for her help with the statistical analysis.

\section{Author details}

'Department of Orthopaedics and Trauma Surgery, University Hospital Heidelberg, Schlierbacher Landstrasse 200a, 69118 Heidelberg, Germany. ${ }^{2}$ Department of Immunology, Heidelberg University, Im Neuenheimer Feld 305, 69120 Heidelberg, Germany. ${ }^{3}$ Department of Pathology, Heidelberg University, Im Neuenheimer Feld 224, 69120 Heidelberg, Germany.

Received: 21 January 2014 Accepted: 10 March 2014

Published: 21 March 2014

\section{References}

1. Learmonth ID, Young C, Rorabeck C: The operation of the century: total hip replacement. Lancet 2007, 370(9597):1508-1519.

2. Goodman SB: Wear particles, periprosthetic osteolysis and the immune system. Biomaterials 2007, 28(34):5044-5048.
3. Shimmin A, Beaule PE, Campbell P: Metal-on-metal hip resurfacing arthroplasty. J Bone Joint Surg Am 2008, 90(3):637-654.

4. Grigoris P, Roberts P, Panousis K, Jin Z: Hip resurfacing arthroplasty: the evolution of contemporary designs. Proc Inst Mech Eng H 2006, 220(2):95-105.

5. Ollivere B, Darrah C, Barker T, Nolan J, Porteous MJ: Early clinical failure of the Birmingham metal-on-metal hip resurfacing is associated with metallosis and soft-tissue necrosis. J Bone Joint Surg (Br) 2009, 91(8):1025-1030.

6. de Steiger RN, Hang JR, Miller LN, Graves SE, Davidson DC: Five-year results of the ASR XL acetabular system and the ASR hip resurfacing system: an analysis from the Australian Orthopaedic Association National Joint Replacement Registry. J Bone Joint Surg Am 2011, 93(24):2287-2293.

7. Steele GD, Fehring TK, Odum SM, Dennos AC, Nadaud MC: Early failure of articular surface replacement XL total hip arthroplasty. J Arthroplasty 2011, 26(6 Suppl):14-18.

8. Langton DJ, Jameson SS, Joyce TJ, Hallab NJ, Natu S, Nargol AV: Early failure of metal-on-metal bearings in hip resurfacing and large-diameter total hip replacement: a consequence of excess wear. J Bone Joint Surg (Br) 2010, 92(1):38-46.

9. Cuckler JM: Metal-on-metal surface replacement: a triumph of hope over reason: affirms. Orthopedics 2011, 34(9):e439-e441.

10. MacDonald SJ: Metal-on-metal total hip arthroplasty: the concerns. Clin Orthop Relat Res 2004, 429:86-93.

11. Park YS, Moon YW, Lim SJ, Yang JM, Ahn G, Choi YL: Early osteolysis following second-generation metal-on-metal hip replacement. J Bone Joint Surg Am 2005, 87(7):1515-1521.

12. Haddad FS, Thakrar RR, Hart AJ, Skinner JA, Nargol AV, Nolan JF, Gill HS, Murray DW, Blom AW, Case CP: Metal-on-metal bearings: the evidence so far. J Bone Joint Surg (Br) 2011, 93(5):572-579.

13. Benson MK, Goodwin PG, Brostoff J: Metal sensitivity in patients with joint replacement arthroplasties. Br Med J 1975, 4(5993):374-375.

14. Pazzaglia UE, Ceciliani L, Wilkinson MJ, Dell'Orbo C: Involvement of metal particles in loosening of metal-plastic total hip prostheses. Arch Orthop Trauma Surg 1985, 104(3):164-174.

15. Willert $H G$, Semlitsch M: Reactions of the articular capsule to wear products of artificial joint prostheses. J Biomed Mater Res 1977 11(2):157-164.

16. Hallab N, Merritt K, Jacobs JJ: Metal sensitivity in patients with orthopaedic implants. J Bone Joint Sur 2001, 83(3):428.

17. Willert HG, Buchhorn GH, Fayyazi A, Flury R, Windler M, Koster G, Lohmann $\mathrm{CH}$ : Metal-on-metal bearings and hypersensitivity in patients with artificial hip joints, a clinical and histomorphological study. J Bone Joint Surg Am 2005, 87(1):28-36.

18. Huber M, Reinisch G, Trettenhahn G, Zweymuller K, Lintner F: Presence of corrosion products and hypersensitivity-associated reactions in periprosthetic tissue after aseptic loosening of total hip replacements with metal bearing surfaces. Acta Biomater 2009, 5(1):172-180.

19. Davies AP, Willert HG, Campbell PA, Learmonth ID, Case CP: An unusual lymphocytic perivascular infiltration in tissues around contemporary metal-on-metal joint replacements. J Bone Joint Surg Am 2005, 87(1):18-27.

20. Natu S, Sidaginamale RP, Gandhi J, Langton DJ, Nargol AV: Adverse reactions to metal debris: histopathological features of periprosthetic soft tissue reactions seen in association with failed metal on metal hip arthroplasties. J Clin Pathol 2012, 65(5):409-418.

21. Campbell P, Ebramzadeh E, Nelson S, Takamura K, De Smet K, Amstutz HC: Histological features of pseudotumor-like tissues from metal-on-metal hips. Clin Orthop Relat Res 2010, 468(9):2321-2327.

22. Ingham E, Fisher J: The role of macrophages in osteolysis of total joint replacement. Biomaterials 2005, 26(11):1271-1286.

23. Hallab N: Metal sensitivity in patients with orthopedic implants. $J$ Clin Rheumatol 2001, 7(4):215-218.

24. Kwon YM, Thomas P, Summer B, Pandit H, Taylor A, Beard D, Murray DW, Gill HS: Lymphocyte proliferation responses in patients with pseudotumors following metal-on-metal hip resurfacing arthroplasty. J Orthop Res 2010, 28(4):444-450.

25. Baldwin L, Flanagan BF, McLaughlin PJ, Parkinson RW, Hunt JA, Williams DF: A study of tissue interface membranes from revision accord knee arthroplasty: the role of T lymphocytes. Biomaterials 2002, 23(14):3007-3014.

26. Kotsougiani D, Pioch M, Prior B, Heppert V, Hansch GM, Wagner C: Activation of T lymphocytes in response to persistent bacterial infection: induction of CD11b and of toll-like receptors on T Cells. Int J Inflamm 2010, 2010:526740. 
27. Gaida MM, Mayer B, Stegmaier S, Schirmacher P, Wagner C, Hänsch GM: Polymorphonuclear neutrophils in osteomyelitis: link to osteoclast generation and bone resorption. European J of Inflammation 2012, 10:413-426.

28. Pfeilschifter J, Chenu C, Bird A, Mundy GR, Roodman GD: Interleukin-1 and tumor necrosis factor stimulate the formation of human osteoclastlike cells in vitro. J Bone Miner Res 1989, 4(1):113-118.

29. Ha J, Lee Y, Kim HH: CXCL2 mediates lipopolysaccharide-induced osteoclastogenesis in RANKL-primed precursors. Cytokine 2011, 55(1):48-55.

30. Henderson B, Nair SP: Hard labour: bacterial infection of the skeleton. Trends Microbiol 2003, 11(12):570-577.

31. Mandelin J, Li TF, Liljestrom M, Kroon ME, Hanemaaijer R, Santavirta S, Konttinen YT: Imbalance of RANKL/RANK/OPG system in interface tissue in loosening of total hip replacement. J Bone Joint Surg (Br) 2003, 85(8):1196-1201.

32. Wada T, Nakashima T, Hiroshi N, Penninger JM: RANKL-RANK signaling in osteoclastogenesis and bone disease. Trends Mol Med 2006, 12(1):17-25.

33. Wagner C, Kondella K, Bernschneider T, Heppert V, Wentzensen A, Hansch GM: Post-traumatic osteomyelitis: analysis of inflammatory cells recruited into the site of infection. Shock 2003, 20(6):503-510.

34. Gesser B, Lund M, Lohse N, Vestergaad C, Matsushima K, Sindet-Pedersen S, Jensen SL, Thestrup-Pedersen K, Larsen CG: IL-8 induces T cell chemotaxis, suppresses IL-4, and up-regulates IL-8 production by CD4+ T cells. J Leukoc Biol 1996, 59(3):407-411.

35. Taub DD, Lloyd AR, Wang JM, Oppenheim JJ, Kelvin DJ: The effects of human recombinant MIP-1 alpha, MIP-1 beta, and RANTES on the chemotaxis and adhesion of T cell subsets. Adv Exp Med Biol 1993, 351:139-146.

36. Qin S, LaRosa G, Campbell JJ, Smith-Heath H, Kassam N, Shi X, Zeng L, Buthcher EC, Mackay CR: Expression of monocyte chemoattractant protein-1 and interleukin-8 receptors on subsets of T cells: correlation with transendothelial chemotactic potential. Eur J Immunol 1996, 26(3):640-647.

37. Sallusto F, Geginat J, Lanzavecchia A: Central memory and effector memory T cell subsets: function, generation, and maintenance. Annu Rev Immunol 2004, 22:745-763.

38. Innocenti M, Carulli C, Matassi F, Carossino AM, Brandi ML, Civinini R: Total knee arthroplasty in patients with hypersensitivity to metals. Int Orthop 2014, 38(2):329-333.

39. Hart AJ, Hester T, Sinclair K, Powell JJ, Goodship AE, Pele L, Fersht NL, Skinner J: The association between metal ions from hip resurfacing and reduced T-cell counts. J Bone Joint Surg (Br) 2006, 88(4):449-454.

40. Wagner $\mathrm{M}$, Klein $\mathrm{CL}$, van Kooten TG, Kirkpatrick CJ: Mechanisms of cell activation by heavy metal ions. J Biomed Mater Res 1998, 42(3):443-452.

\section{Submit your next manuscript to BioMed Central and take full advantage of:}

- Convenient online submission

- Thorough peer review

- No space constraints or color figure charges

- Immediate publication on acceptance

- Inclusion in PubMed, CAS, Scopus and Google Scholar

- Research which is freely available for redistribution 